\title{
SCIENTIFIC PERSONAS IN THEORY AND PRACTICE - WAYS OF CREATING SCIENTIFIC, SCHOLARLY, AND ARTISTIC IDENTITIES
}

\author{
Kirsti Niskanen, Mineke Bosch, KaAt Wils
}

The concept of scientific persona was developed by historians of science at the Max Planck Institute in Berlin fifteen years ago in order to understand how science works and how it can be conducted in a credible way. The Latin word persona means mask and the discussions of the term were elaborations of Marcel Mauss's introduction of the concept in an article published in 1938 (Mauss 1938). In Mauss's conceptualisation, persona was a feature that characterized societies in an evolutionary stage-a stage where members of the society had started to perceive themselves as individuals, but were still expected to fulfill certain, culturally defined roles. In such contexts, persona was not a mask to cover the 'real' self of the performer, but a mask that enhanced certain features of the person. Transferring Mauss's approach to the scientific world, Lorraine Daston and Otto Sibum (2003) defined, in an often cited article in Science in Context, scientific persona as an intermediate between individual biography and social (scientific) institution: it is a cultural identity that forms the individual in body and mind, and creates a collective with a shared and recognizable physiognomy (ways to be and to behave). Daston and Sibum characterized scientific personas as templates that emerge and develop in historical contexts and used the concept to investigate the creation of certain types of scientists: when, how and why have distinct "scientific personae" emerged?

Scientific personas are historical constructions; they are not just a mask or a role that individuals assume or shape and are shaped by. They are collective entities, a kind of cultural and social repertoires on how to be a person of science. In the creation of, or habituation to, a persona, imitation and adaptation play an important role (Goffman 1959). In many cultures, personas are incarnations of a tradition, and creating a new persona is a delicate balance between old and new cultural forms (Daston \& Sibun 2003). In addition to the need to create a personal identity, constructions of persona are important because they exemplify new ways of being in the world, and also form the basis for the creation of trustworthiness, reliability, and predictability on social interaction. Especially in scientific communities, trust in one's person is essential because it is impossible for us to solely rely on our own observations-that would mean that every claim would have to be tested over and over again and each empirical or archive-based information be subjected to control, as Mineke Bosch (2013) has noted.

The above mentioned special issue of Science in Context presented historical examples of scientific personas: the aristocratic independent scientist; the religiously inspired, ascetic, and sickly genius; the absent-minded professor (the repertoire of "learned forgetfulness"); and the modest, humble, self-taught scientist. With the professionalisation of science at the end of the eighteenth and the beginning of the twentieth century, new forms of scientific being were developed, influenced by American entrepreneurial examples and promoted by new forms of research funding (Shapin 2008). In this perspective, it is interesting to ask: how do collective 
constructions of scientific personas emerge and develop in changing historical contexts? In what ways are these constructions cemented, and transferred across national borders and to subsequent generations? How do scientific personas shape, and are shaped by, the individuals who incorporate them? What purposes do these constructions serve? And what is the relationship between the scientist, or the scholar, as a person and the content of science?

Empirical work and discussions on the concept have burgeoned since Daston and Sibum introduced the term in 2003. One example is a research group at Leiden University directed by Herman Paul. Tying in with the field of historical epistemology, Paul developed a more specific understanding of the concept "scholarly persona" or "scholarly self" as a set of discipline specific virtues and skills that are deemed necessary in order to work and to be recognized as an academic historian (Paul 2014, Paul 2016a, Paul 2016b). The articles presented in this special issue of Persona Studies represent another expansion of the concept. While gathering insights from earlier discussions, the essays elaborate new kinds of theoretical and empirical uses of the term. Several contributions in this issue result from an international research project, Scientific Persona in Cultural Encounters (SPICE). The project has nuanced and complicated the concept of scientific, or scholarly, persona in (at least) two important ways. Firstly, our investigations are (following Shapin 1994, 2008, Goffman 1959, Butler 1990, Bosch 2013,2018 ) based on the idea of a dynamic relationship between credibility in scientific assertions and the ways in which researchers perform and embody their identities as trusted and credible scientists, and how their personas are influenced and shaped by social categories such as class, gender, ethnicity and/or religious affiliation. Following the literary scholar Lies Wesseling's (2004) analysis of the developmental psychologist Judith Rich Harris, Bosch (2016) shows in an investigation of Dutch historians that rather than a historical cavalcade, it is more fruitful to explore scholarly personas as bricolage where existing, old repertoires, ideals and academic identities are performed, overlap and mix with new ideals, depending on the specific persons and contexts involved.

Secondly, a component of our research deals with the very definition of scientific (or scholarly) persona, and the empirical contexts, source materials and methods used to study the creation of academic identities. Scientific persona has so far mostly been studied at the individual level and perceived as an individual self-formation, imitation, and adaptation to the available and current scientific repertoires, norms, and value systems. Our empirical results have led us to partially redefine the term. Scientific personas are also created by institutions and institutional conditions. In addition to a person's self-conception, persona is also about office, those personal qualities, roles and responsibilities which are associated with holding a scientific position, at a particular historical time and place (Condren, Gaukroges, Hunter et al. 2006). An example of a persona shaping scientific position is a professor's chair - a position with the succession of office holders - which even today can provide the person who conquers the chair with a reputation and a certain aura, like William Clark (2006) notes in his discussion of academic charisma. Our investigations demonstrate that internalization and institutionalization of research influenced the scientific landscapes of the first part of the twentieth century by creating new forms of funding, related to specific research areas. Through selection and evaluation processes, these new economic structures contributed both to defining what was 'good' and 'important' research and who were perceived as 'good', recognized scientists. SPICE has so far studied research policy and selection mechanisms focusing on the Belgian American Educational Foundation (BAEF) in Belgium (Huistra \& Wils 2016), the Rockefeller Foundation's scholarship programs in Sweden (Niskanen 2016, 2017) and the International Federation of University Women's research and scholarships programs aimed at women researchers (Cabanel 2015). The studies show that research funders have acted as gatekeepers, that they have 
defined what a "good" scientist or scholar looks like (both literally and in a figurative sense), and that they therefore have influenced the creation of scientific identities.

\section{THE CONTRIBUTIONS}

The essays in this issue demonstrate the richness and variety in which the persona concept can be used as a tool for studying the creation of scientific, academic and research oriented selfconceptions, and professional and vocational identities, as well as how institutions contribute to the shaping of scientific ways of being. They also show that knowledge creation, be it strictly scientific, vocational, or artistic, is embedded in social categories of gender, class and race.

The seven articles that make up this issue discuss and develop the use of scientific persona concept empirically and theoretically. They can be grouped into themes that highlight different approaches to scientific identity formation. The first theme is about embodied knowledge, the intertwining of knowledge, the creator of knowledge as a person, and the object of knowledge. The issue opens with Josephine Hoegaert's article "Chewing Demosthenes's Pebbles: Embodied Experience Making the Scientist's Persona, ca 1830-1910”. Hoegaert illustrates how the field of knowledge about voice and its functions were, literally, based on bodily experience of the experts who developed the area into a scientific field during the last part of the nineteenth century. Since the study objects of laryngology and phoniatry were inside the body, inaccessible for observation, non-normative bodily experiences, such as stammering, could be mobilised to construct a credible scientific persona. The reliance on embodied experience opened opportunities for non-conventional scientific actors-including women-to assert themselves as experts in the field. Lisa Svanfeldt-Winter's article "Writing a folklorist's persona in the field: How defining the object of study defines the scholar" also encourages reflection on how the creation of scholarly persona is related to the scientific object of study. Folkloristics played an important role in the creation of national identity in the early 20 th century Finland. The discipline's method was to document and explore the 'authentic' national cultural heritage by collecting poems, songs and dialects in meetings with informants in the field, often in the rural areas of eastern Finland, which was perceived as 'unspoiled'. SvanfeldtWinter shows how young folklorists' scholarly persona was shaped through processes of identification with, and distance from, the research object, i.e. informants in the field.

The second theme deals with autobiographical representations of scholarly and professional persona. In both Rozemarijn van de Wal's article "Constructing the persona of a professional historian: On Eileen Power's early career persona formation and her year in Paris, 1910-1911" and in Amy Rubens's "Enacting self and scientific persona: Models for women health professionals in Dr. S. Josephine Baker's Fighting for Life, the discussion about autobiographical performativity plays a central role. Eileen Power became professor of Economic History at the London School of Economics and a renowned medieval historian, and Josephine Baker was a pioneer for women health professionals in New York in the 1920s. Although they deal with different contexts, both articles show how autobiographical actsnotes and diaries in Power's case and an autobiography in Baker's-facilitate the interaction between individual identity (a person) and cultural template or model (a persona). Van de Wal shows how Power began to shape her own academic and professional identity during her year in Paris by incorporating elements from different areas-from feminism, history and the artsand how this process was the start of the creation of her scholarly persona as an Oxbridge scholar. This required being well-connected, well-versed in the arts, as well as trained in the newly developed, professional, document-based history of the famous school of Langlois. Similarly, Rubens shows how Baker built up a scientific and professional persona by adopting prevailing personas for women health professionals but also by altering the dominant model for 
female doctors. Baker's reformulation of a prevailing concept of scientific motherhood in her work among immigrants in New York, in a class-based context, marked a reshaping of available personas for women health professionals.

A third, related theme deals with the gendered opportunities for women to create a recognized, credible scientific and artistic personas at a time when women were prevented from, or not expected, to have visible and authoritative positions in the public sphere. Julia Dahlberg's s article "When Artists Became Intellectuals: Science as a Significant Other for the Female Artistic Persona" shows how the artist, writer, and social activist Helena Westermarck created a public intellectual persona by borrowing status and authority from the scientific persona of her brother, internationally renowned philosopher and professor of sociology, Edward Westermarck. The grounds for the creation of a scientific persona were several for the protagonist of Sarah Erman's article. "A teacher, a scientist, a wife: the complex self of Joséphine Schouteden-Wéry (1879-1954)”. Schouteden-Wery was married to a well-known scientist but she was also a teacher and popular science writer who combined repertoires from the different fields in order to carve herself a place in the scientific community.

The final article in the issue deals with the question of how organizations and their cultures contribute to creating and shaping academic identities. Women entered universities and institutions of higher education slowly during the first part of the twentieth century. As Anna Cabanel shows in "How excellent ... for a woman? The fellowship program of The International Federation of University Women (IFUW) in the interwar period", the International Federation of University Women was founded as a counterweight to the organizations that mainly supported men. Its aim was to provide women researchers access to scholarships and research opportunities that opened the way to academic positions. Cabanel demonstrates that the fellowship programme was meant to function as a meritocratic and excellence-oriented system. Deliberately understating aspects of gender and developing a strictly meritocratic discourse, the Federation promoted a "disembodied" type of scientific persona as a strategy aimed at overcoming a long-standing bias against the alleged amateurism of women scientists.

Last but not least: The concept of persona is, of course, used not only in the history of science, but also in cultural studies where persona studies has established itself as a research field at the side of celebrity studies, this journal being an example of this development. We pride ourselves on the opportunity to edit the journal's first special issue with focus on history and the history of science.

\section{WORKS CITED}

Bosch, M 2013. "Persona and the Performance of Identity: Parallel Developments in the Biographical Historiography of Science and Gender, and the Related Uses of Self Narrative". L'Homme. Europäische Zeitschrift für Feministische Geschichtswissenschaft, vol. 24, no. 2, pp. 11-22.

Bosch, M 2016. "Scholarly Personae and Twentieth-Century Historians: Explorations of a Concept". BMGN-Low Countries Historical Review, vol. 131, no. 4, pp. 33-54.

Bosch, M 2018. "Looking at Laboratory Life, Writing a (new) Scientific persona. Marianne van Herwerden's travel letters from the United States, 1920". L'Homme. Europäische Zeitschrift für Feministische Geschichtswissenschaft, vol. 29, no. 1, pp. 15-33.

Butler, J 1990. Gender Trouble: Feminism and the Subversion of Identity, London. 
Cabanel, A 2015. "Pionnières du Nord - Universitaires norvégiennes et réseaux féminins internationaux (1882-1940)". Genre \& Histoire. La revue de l'Association Mnémosyne, vol. 15, http://journals.openedition.org/genrehistoire/2110.

Clark, W 2006. Academic Charisma and the Origins of the Research University. Chicago, University of Chicago Press.

Condren, C, Gaukroger, S \& Hunter, I 2006. The Philosopher in Early Modern Europe: The Nature of a Contested Identity. Cambridge University Press, Cambridge.

Daston, L \& Sibum, 0 2003, "Introduction: Scientific Personae and Their Histories", Science in Context, vol. 16, no. 2, pp. 1-8, DOI 10.1111/hith.10717.

Goffman, E 1959. The Presentation of Self in Everyday Life. Garden City, Doubleday.

Huistra P \& Wils K 2016. "Fit to Travel. The Exchange Programme of the Belgian American Educational Foundation: An Institutional Perspective on Scientific Persona Formation (1920-1940)". BMGN-Low Countries Historical Review, vol. 131, no. 4, pp. 112-134.

Mauss, M 1938. “Une catégorie de l'esprit humain: La notion de personne. Celle de 'moi'. Un plan de travail". Journal of the Royal Anthropological Institute CH, pp. 236-281. doi: 10.1522/cla.mam.cat

Niskanen, K 2016. “Searching for 'Brains and Quality'. Fellowship Programs and Male Constructions of Scientific Personae by the Rockefeller Foundation in Sweden During the Interwar Period'. Paper presented at The 7th International Conference of the European Society for the History of Science , 22-24 September, Prague, Czech Republic.

Niskanen, K 2017. "Snille efterfrågas! Rockefeller Foundation, forskarpersona och kön vid Stockholms högskola". Scandia vol. 83, no. 2, pp. 11-40.

Paul, H 2014. "What Is a Scholarly Persona? Ten Theses on Virtues, Skills, and Desires". History and Theory vol. 53, pp. 348-371.

Paul, H 2016a. "Sources of the Self. Scholarly Personae as Repertoires of Scholarly Selfhood". BMGN - Low Countries Historical Review, vol. 131, no. 4, pp. 135-154.

Paul, H 2016b. "The Virtues and Vices of Albert Naudé: Towards a History of Scholarly Personae". History of the Humanities, vol. 1, no. 2, pp. 327-338.

Shapin, S 1994. A Social History of Truth: Civility and Science in Seventeenth-Century England. University of Chicago Press, Chicago.

Shapin, S 2008. The Scientific Life: A Moral History of a Late Modern Vocation. Chicago, University of Chicago Press.

Wesseling, E 2004. "Judith Rich Harris: The Miss Marple of Developmental Psychology". Science in Context, vol. 17, no. 3, pp. 294-314. 